\title{
DYNAMICS AND SEQUENTIAL ANALYSIS OF A MESOTIDAL SHOAL AND INTERSHOAL CHANNEL COMPLEX IN THE EASTERN SCHELDT (SOUTHWESTERN NETHERLANDS) *
}

\author{
SWIE-DJIN NIO, JAN H. van den BERG, M. GOESTEN and F. SMULDERS \\ Comparative Sedimentology Division, Institute of Earth Sciences, State \\ University of Utrecht, (The Netherlands)
}

(Received September 12, 1979)

\section{ABSTRACT}

Nio, S-D., Van den Berg, J.H. Goesten, M. and Smulders, F., 1980. Dynamics and sequential analysis of a mesotidal shoal and intershoal channel complex in the Eastern

Scheldt (south western Netherlands). Sediment. Geol., 26: 263-279.

A detailed survey was carried out on a mesotidal shoal and intershoal channel complex near the mouth of the Eastern Scheldt in the south western part of The Netherlands during the summers of 1976 and 1977 . The objectives were to establish a relationship between the morphological changes through time and its influence on the development of the preserved sedimentary sequence.

The investigated area is divided into four zones, each one characterized by specific depositional processes and their related bedforms:

(a) the outer channel bend and margin, which is mainly covered by flood-oriented large-scale catenary ripples and sand waves;

(b) the channel thalweg and inner bend, which is dominated by ebb-oriented megaripples;

(c) the inner channel margin, which is characterized by a levee wall;

(d) the adjacent shoal areas, which generally are flat but may be covered by patches of flood- or ebb-oriented large-scale ripples.

The preserved vertical sequence of sedimentary structures in each zone is more or less in accordance with the presence of the dominant bedforms within the respective zones. Sequential analysis shows that the net sedimentation within the outer channel margin is much less when compared to the sediment accumulation within the inner channel margin. This means that the lateral accretional units of the inner channel margin are a dominant feature within the preserved sequence of such a shoal and intershoal channel complex, and also that the preservation potential of sedimentary structures in the inner margin sequence is considerable higher as that compared to the outer margin sequence.

Consequently, preservation of the megaripples, a major bedform in a large part of the investigated area, will be limited and will form only a minor part within an ancient analoguous sequence.

* Comparative Sedimentology Division, Report no. 24. Address: Budapestlaan 4, P.O. Box 80.021, 3508 TA, Utrecht, The Netherlands. 


\section{INTRODUCTION}

The Eastern Scheldt is situated in the southwestern part of The Netherlands and belongs to a system of larger and smaller estuaries and tidal inlets, which are in part in connection with the Rhine-Meuse-Scheldt fluvial system (Fig. 1). This paper presents a discussion on some preliminary results of our studies of a shoal and intershoal channel complex located near the Eastern Scheldt mouth.

During the last decade many studies have been carried out concerning the relationships between sedimentary bedforms, their internal structures and their contemporary arrangement in many inshore tidal environments that have a physiographic setting more or less comparable to our study area (e.g., Oomkens and Terwindt, 1960; Reineck and Singh, 1967; Boersma,
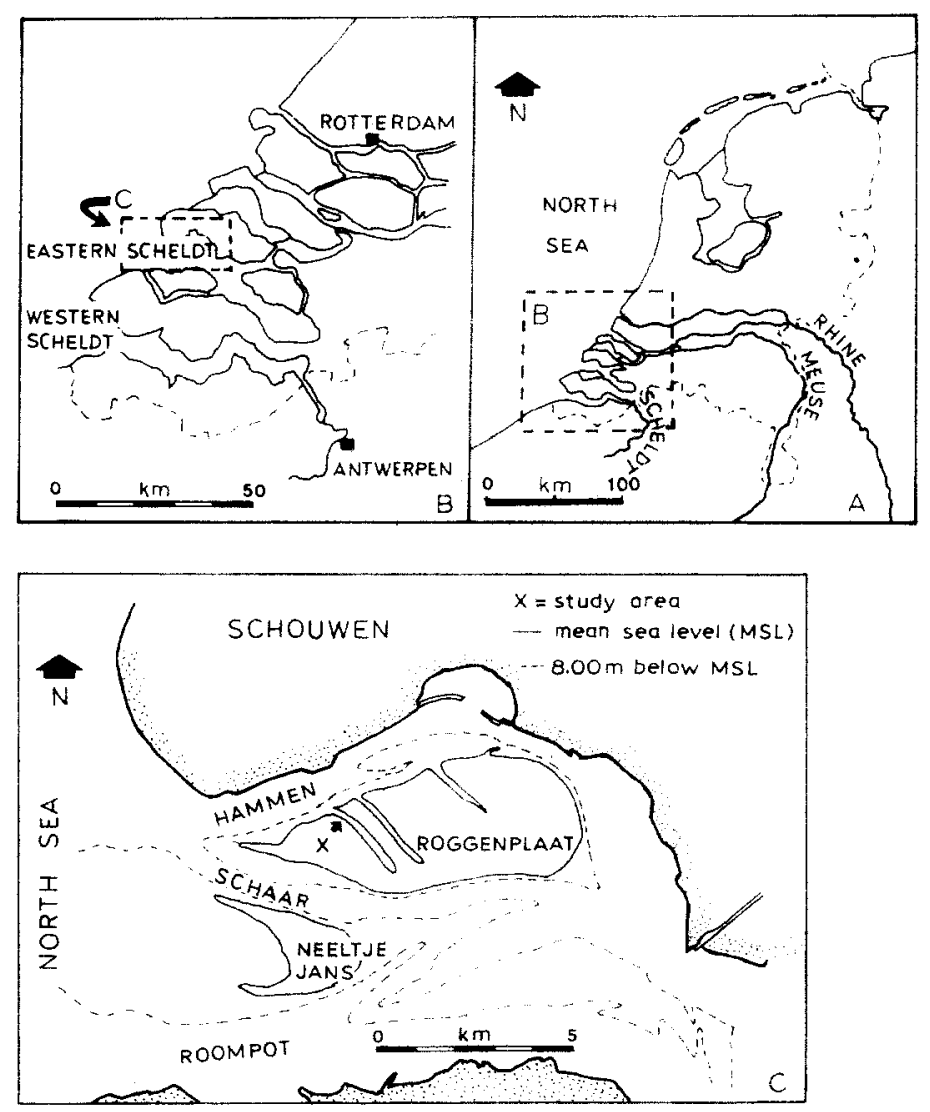

Fig. 1. Location maps. A. Estuarine and tidal inlet area of the southwestern part of The Netherlands; B. Eastern Scheldt and its adjacent estuarine and tidal inlet systems; C. The study area within the Eastern Scheldt. 
1969; Boothroyd, 1969; Klein, 1970; Boothroyd and Hubbard, 1975; Howard and Frey, 1975; Hayes, 1975; Allen and Friend, 1976; Hayes, 1980; this issue).

Investigations of bedforms and their internal sedimentary structures in relation to morphological changes through time and its influence on the development of the preserved sedimentary sequence, however, are still few (e.g., Reineck and Wunderlich, 1969; Terwindt, 1971, 1975; De Raaf and Boersma, 1971). Such data is valuable for the interpretation of ancient analogues. The purpose of this paper is to show such a relationship from a mesotidal inshore environment, where shoals and their dynamically intersecting channels are dominant.

\section{METHODS}

Patterns of currents produced by the tides in the Eastern Scheldt can largely be derived from their morphological elements in flood, ebb and 'neutral' channels and from the directional parameters shown by the bedform configurations. More exact data is obtained from current measurements carried out by Rijkswaterstaat (The Netherlands Governmental Board of Ways, Waterways and Harbours; mostly in unpublished internal reports).

To obtain more detailed information about the characteristics of the tidal currents within the area, few continuous current measurements, covering several spring and neap tidal cycles during the summers of 1976 and 1977 were made. These measurements were carried out with OTT current meters (type 10.002) fitted on stakes and placed at selected points. Simultaneously bedform development and migration was measured during low tide along fixed lines.

To collect undisturbed samples of the preserved sedimentary structures in the subsurface within the intertidal zone, the groundwater level was lowered locally down by $2 \mathrm{~m}$ by means of well drainage that enabled us to cut fairly deep trenches. Sedimentary structures in trench walls were sampled by making lacquer peels according to the procedure described by Bouma (1969), using the fast drying lacquer CL 28 (Sigma Coatings Co., The Netherlands). At the bottom of these trenches and also in subtidal shallow channels, undisturbed cores with a length of $1.10 \mathrm{~m}$ were taken. Coring and lacquering procedures have been described by Van den Berg (1977).

\section{SETTING OF THE STUDY AREA}

The formation of the Eastern Scheldt basin took place during the latest Holocene rise in sealevel. The larger and smaller estuaries and tidal inlets are interconnected and are in part also in connection with the Rhine-MeuseScheldt fluvial system (Fig. 1). The Eastern Scheldt, which was formerly a major course of the Scheldt river, gradually lost its importance as a river distributary since early Medieval times in favour of the more southerly 
located Western Scheldt. In 1867 an unimportant remnant of the connection with the Scheldt River was closed by a dam.

The present-day Eastern Scheldt consists of three major tidal channels: in the south the Roompot and more to the north the Schaar and the Hammen, respectively (Fig. 1,C). These larger tidal channels are separated by several shoals, which are dissected by smaller intershoal channels.

With a mean tidal range of about $3.00 \mathrm{~m}$ the environment is mesotidal according to the classification of Davies (1964). Mean spring and neap tidal ranges are $3.50 \mathrm{~m}$ and $2.30 \mathrm{~m}$, respectively.

Around 1000 A.D., the Eastern Scheldt system was far less important than it is nowadays and consisted of only one major channel (Wilderom, 1964). Extensive inundations and channel erosion of the bordering mainland areas caused an enlargement of the Eastern Scheldt tidal basin and also an increase of the tidal discharge. Especially mainland areas located at the outer bank of major channel bends, appeared to be vulnerable sites for erosion, which could not be prevented by early coastal defence works.

Around 1400 A.D., the early Hammen, located close to the southern margin of the present-day Roggenplaat shoal, developed such a bend. Because of erosion along the outer bend a retreat of the southern coastline of the island of Schouwen occurred between 1400 and 1600 A.D. At the same time, the channel gradually shifted its position to the north and within the inner bend the early Roggenplaat shoal came into existence. It can be assumed that the depth of the Hammen channel thalweg was about $10 \mathrm{~m}$ or more in 1400 A.D. During the shifting to the north, which caused an erosional retreat of the Schouwen mainland, the channel thalweg must have retained or increased its depth together with an increase of its tidal discharge. It can also be assumed that at least the upper $10 \mathrm{~m}$ of sediment in the present-day Roggenplaat shoal were deposited after 1400 A.D. During the 17 th century the Roompot began to develop into a major tidal channel. Presumably, part of the Hammen tidal discharge was diverted into this channel, which resulted in a temporarily lower erosional rate along its outer bend.

Since 1900 A.D., however, tidal discharge within the Hammen has been considerably increased owing to a number of human interferences with the hydraulic situation of the Eastern Scheldt. Because of improved coastal defense works, coastal retreat of the Schouwen mainland was limited and erosional processes along the outer bend of the Hammen shifted to the channel floor, which was eroded locally to more than $50 \mathrm{~m}$ below sealevel.

A reconstruction of the depositional pattern of the Roggenplaat shoal from 1827 till 1953 shows mainly a general accretion of the northern and western margin of the shoal in connection with the northward shift of the major channel (Fig. 2; Fermont, 1977). Erosion and sedimentation along the margins of the Roggenplaat shoal is mainly influenced by the major tidal channels; the inner parts, however, are mainly controlled by the shifting of the numerous intershoal channels (depths generally down to $10 \mathrm{~m}$ ). 


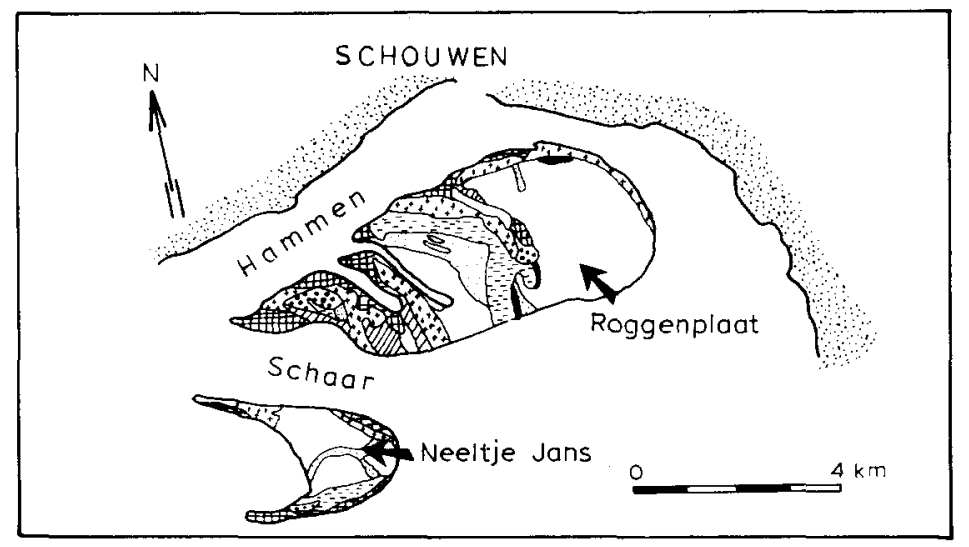

$$
\begin{array}{lll}
\text { SHOAL ACCRETION } & \text { BETWEEN: } & \text { ED } 1899-1912 \\
\because 1827-1860 & \because 1872-1886 & 1912-1933 \\
1860-1872 & \because 1886-1899 & 1933-1953
\end{array}
$$

Fig. 2. Accretion of the Roggenplaat shoal during the period 1827-1953 (mainly after Fermont, 1977).

\section{MORPHODYNAMICS AND BEDFORM DEVELOPMENT OF THE INTERSHOAL CHANNEL AND ADJACENT AREA}

The numerous intershoal channels of the Roggenplaat shoal show a distinct drainage pattern to the $\mathrm{NW}$, where these minor channels are in open connections with the Hammen (Fig. 3). Flood currents are dominant along the inner bend of the Hammen as can be seen by the dune morphology and are largely responsible for accretional and erosional processes along the northern margin of the Roggenplaat shoal. Flood currents entering the smaller intershoal channels are, because of inertial forces, restricted to the outer channel bend (Fig. 4). The outer channel margin and adjacent shoal area become inundated at a later stage of the flood. Current velocities measured at location CM (see Fig. 4) within the outer channel margin show maximum flood current velocities of $1.20 \mathrm{~m} / \mathrm{s}$ during spring-tide and $0.70 \mathrm{~m} / \mathrm{s}$ during neap-tide.

A stagnation of the watermasses on the shoal generally occurs during ebb and discharge takes place through the deeper parts of the intershoal channel. Ebb currents are, therefore, dominant within the slightly meandering thalweg of the intershoal channel (see Fig. 6). Evidence of flood and ebb dominance is reflected by the occurrence of the respective bedforms. The outer channel margin and adjacent shoal are characterized by flood-dominated bedforms, the channel thalweg and inner channel margin by ebbdominated bedforms. Distinct flood-and ebb-dimonated zones are separated from each other by a narrow zone that has transitional bedforms (see Fig. 4).

Evidence for a flood dominance within the outer channel margin and 


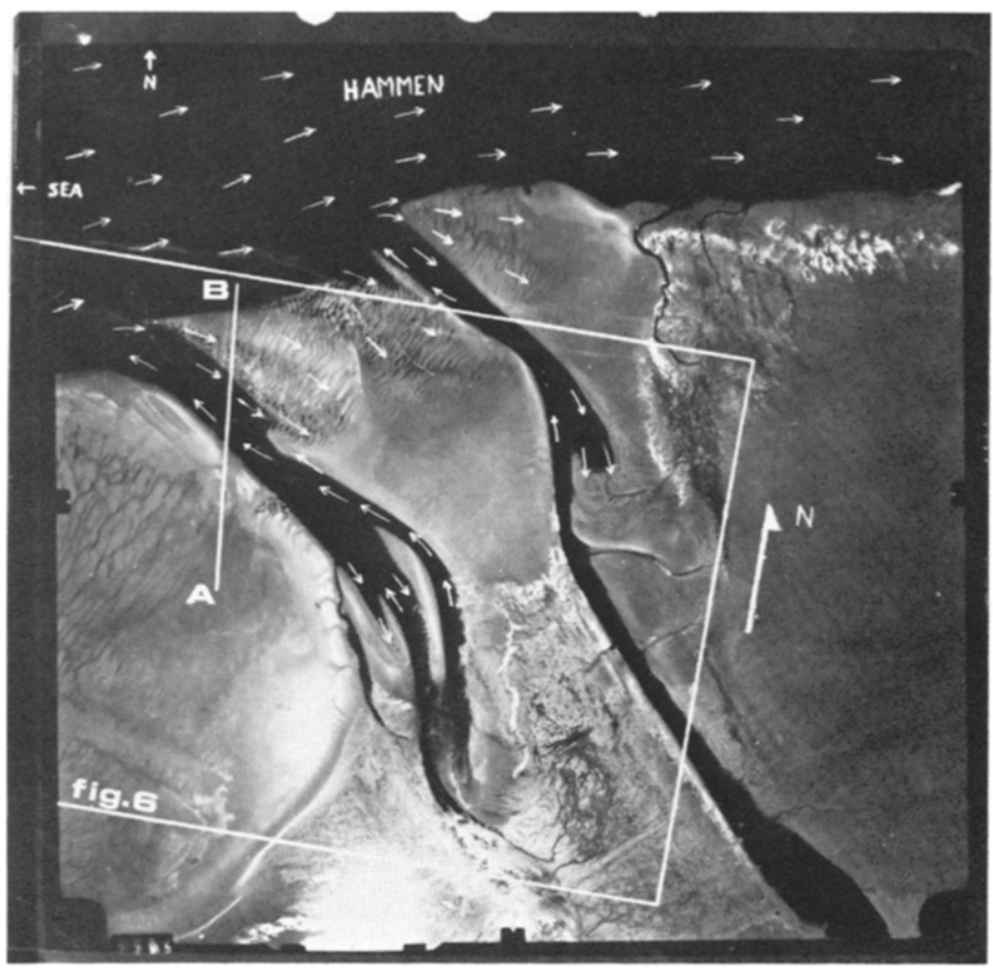

Fig. 3. Aerial view of the northwestern part of the Roggenplaat shoal. Note that flood currents are dominant along the northern margin of the shoal and are restricted to the outer bend of the intershoal channels. $A-B$ line of measured section (see Figs. 6 and 7 ).

adjacent shoal is also found by the asymmetry of the time-velocity curves (fig. 5). The average flood-ebb period is $6 \mathrm{~h}$ and $20 \mathrm{~min}$. Wind conditions, however, can prolong or shorten the flow period of flood or ebb. The lateral flow expansion of the flood current to outer channel margin and adjacent shoal accounts for a gradual decrease in flow strength in an eastward direction. This results in a distinct lateral sequence of bedforms, which show catenary large-scale ripples in the western part of the area to slightly sirusiodal sand waves in the east. Similar lateral bedform sequences are described by Boothroyd and Hubbard (1975) in the Parker and Essex estuaries in the United States. Sand wave migration within the outher channel margin mainly takes place during spring-tides and is only produced by flood currents. Current velocities during neap-tides (less than $0.50 \mathrm{~m} / \mathrm{s}$ ) are too low to generate a constructive ripple migration and a temporary degeneration of the megabedforms will take place, which also results in a gradual reduction of ripple amplitudes and a flattening of their lee-side slopes.

A distinct feature within the area is the presence of a prominent levee along the inner bend of the intershoal channel (L3 in Figs. 4 and 7). The 


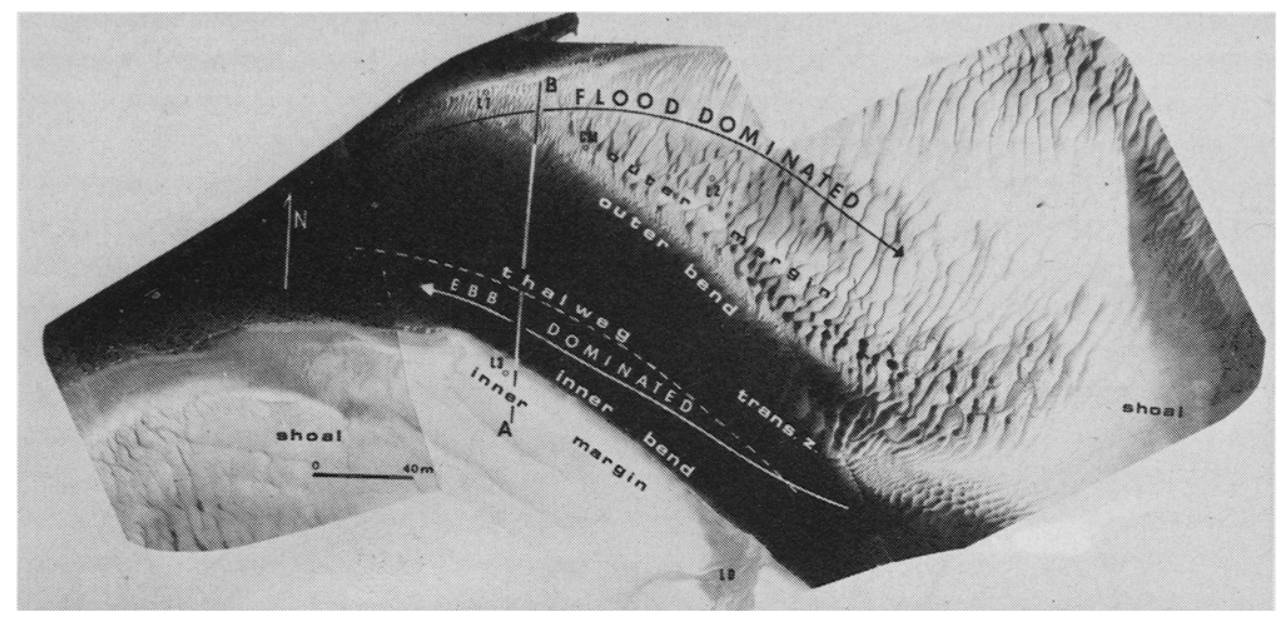

Fig. 4. Detailed aerial view of the study area. Note that the different zones are characterized by specific bedforms. The transitional zone (trans.z.) consist of unstable flood- or ebb-oriented bedforms. $L 1, L 2$ and $L 3$ are lacquer peel locations; $L D$ is a delta-like fan, formed by small gullies during ebb tide; $C M$ is the location where current-velocity measurements were made.

highest point of this levee is $0.90 \mathrm{~m}$ above MSL or $0.20 \mathrm{~m}$ above the adjacent shoal. The morphology of this levee is characterized by a gentle slope to the adjacent shoal and a steep slope gradient to the channel (slope angle up to $13^{\circ}$ ). The surface of the levee is characterized by small-scale bedforms, such as wave ripples. Large-scale bedforms are not present, but they are common on the adjacent shoal, which consist of flood-dominated

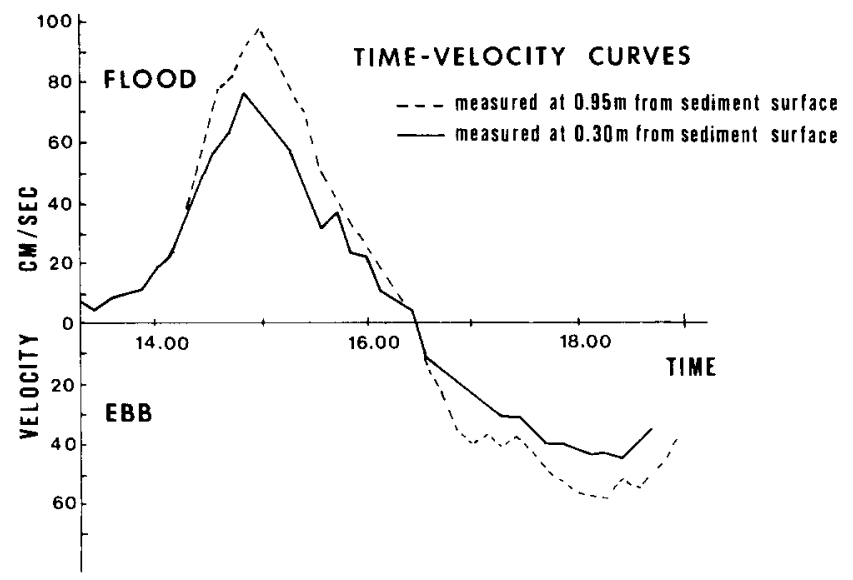

Fig. 5. Time-velocity curves measured one day after spring-tide. Average flood-ebb period is $6 \mathrm{~h}, 20 \mathrm{~min}$. Wind conditions caused a longer flood-current period during the measurements. 

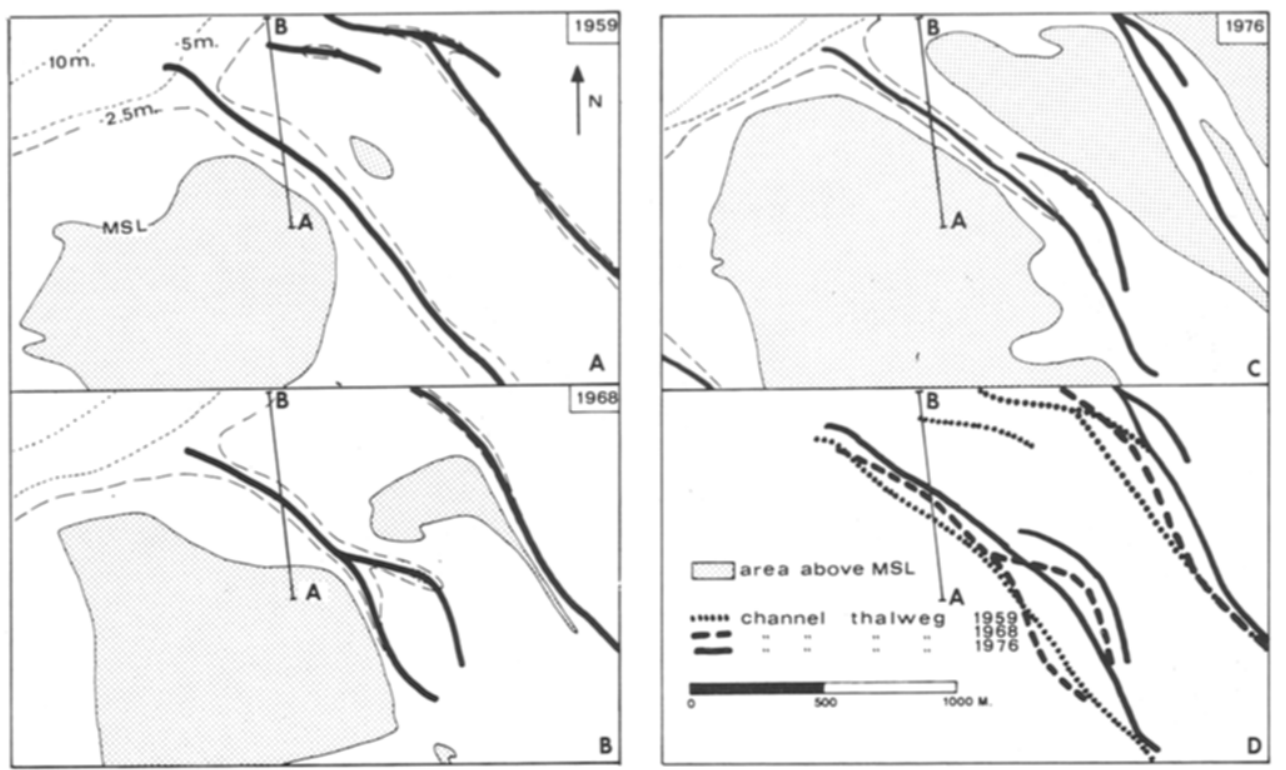

Fig. 6. Morphological changes of the shoal and intershoal complex in the period between 1959 and 1976. Note the net sediment accumulation within the study area, which is associated with a decrease of the tidal discharge. Note also the slight meandering of the ebb-dominated channel thalweg.

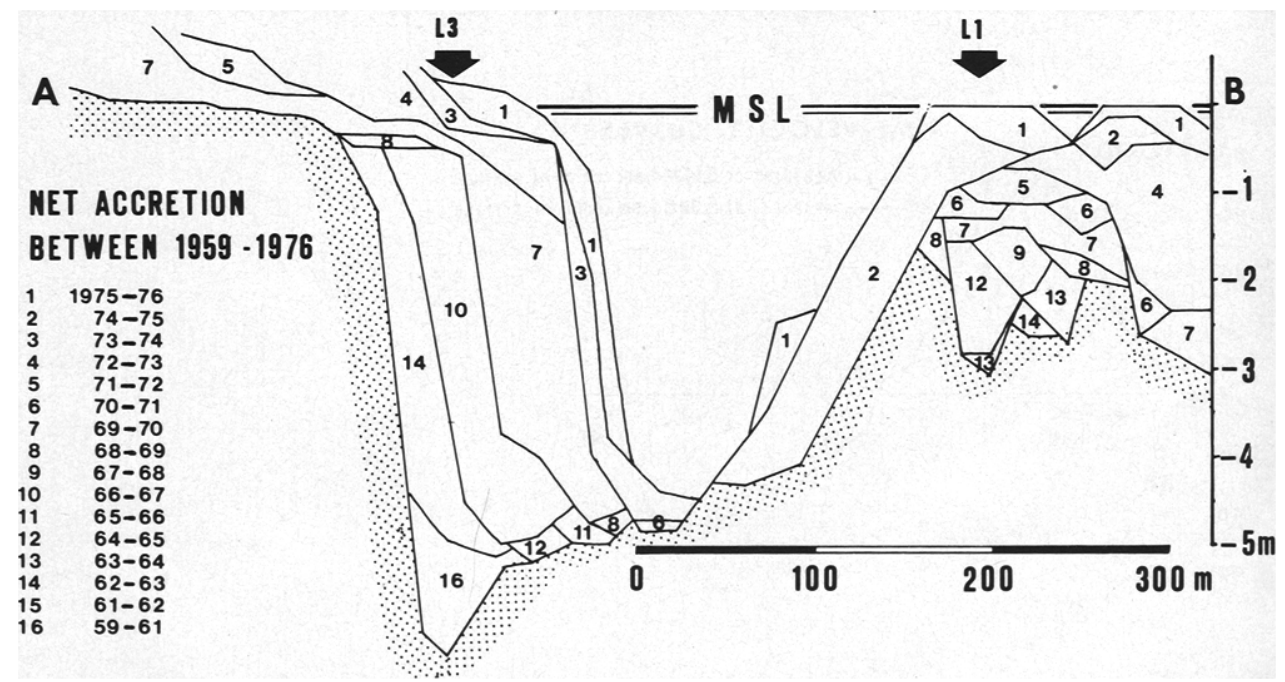

Fig. 7. Cross-section $A-B$ through the study area (for location, see Fig. 4) showing net accretional units in the period between 1959 and 1976. 
sand waves. Because of the relatively high level of the levee with respect to MSL, flood currents generally reach this zone during a late stage of rising water and current strength is unsufficient to generate large-scale bedforms. These flood-dominated sand waves, therefore, decrease towards the levee. Consequently, little or no sediment is transported during flood tide across the levee when normal weather conditions are prevailing. During periods of moderate to strong westerly onshore winds, however, sediment transport across the shoal will be increased by winddrift currents and wave oscillation. This results in a considerable amount of sediment transport across the levee at flood. Also, the generally SE-NW trending intershoal channels act as sediment traps and most of the sediment will be deposited on the channel-side slopes of the levee. The slope gradient tends to increase after such a depositional period, but will decrease during low tide, when ebb currents will remove part of the sediment again.

Strong onshore winds generally also influence the intertidal bedforms. Wave action will especially affect those areas that are exposed to incoming shoaling waves, such as the outer channel margin and adjacent shoal. During such periods most of the megaripples will be completely flattened.

With moderate easterly winds, an eastward sand transport to the channel is diminished or halted. Instead some minor swash and backwash action, on the steeper channel bank account for a temporary levee elevation as a swash bar (King and Williams, 1949). The levee disappears gradually as soon as westerly winds return.

At ebb tide, the levee and its adjacent shoal is drained by the intershoal channel and when flow to the intershoal channel is hindered by the levee wall during the final ebb stage, it will be restricted to a few low points in the levee where small erosional small gullies become formed. Most of the eroded material is deposited by these gullies in delta-like fans near the lowwater line along the inner bend of the intershoal channel (Fig. 4, location LD).

Detailed echo-sounding measurements in the period between 1959 and 1976, carried out by The Netherlands Rijkswaterstaat, show a lateral shifting of the intershoal channels on the Roggenplaat shoal toward the east. This channel migration may be considered as the combined effect of lateral accretion of the inner channel margin or channel westbanks during onshore wind conditions and also as erosional processes on the outer channel margin or eastbanks by the flood currents. In addition, these measurements show that during the last decades a very important overall net accretion occurred in and around the study area (Fig. 7). This accretion resulted in a reduction of the channel section and, consequently, a reduction of the tidal discharges.

SEQUENTIAL DEVELOPMENT OF THE INNER AND OUTER INTERSHOAL CHANNEL MARGINS

The sediments within this area consist of medium- to fine-grained sand. The sequential development at three locations within the most specific zones 
of the margins of the intershoal channel are discussed below in more detail (see Fig. 4 for locations):

(1) Figs. 8A, B show a preserved vertical sequence of sedimentary structures sampled at the outer margin near the intershoal channel mouth. At this location, bedforms mainly consist of catenary flood-oriented large-scale ripples, which develop sharply pointed saddles and deep embayed lobes. The short-crested ripple trains generally pass laterally into disconnected
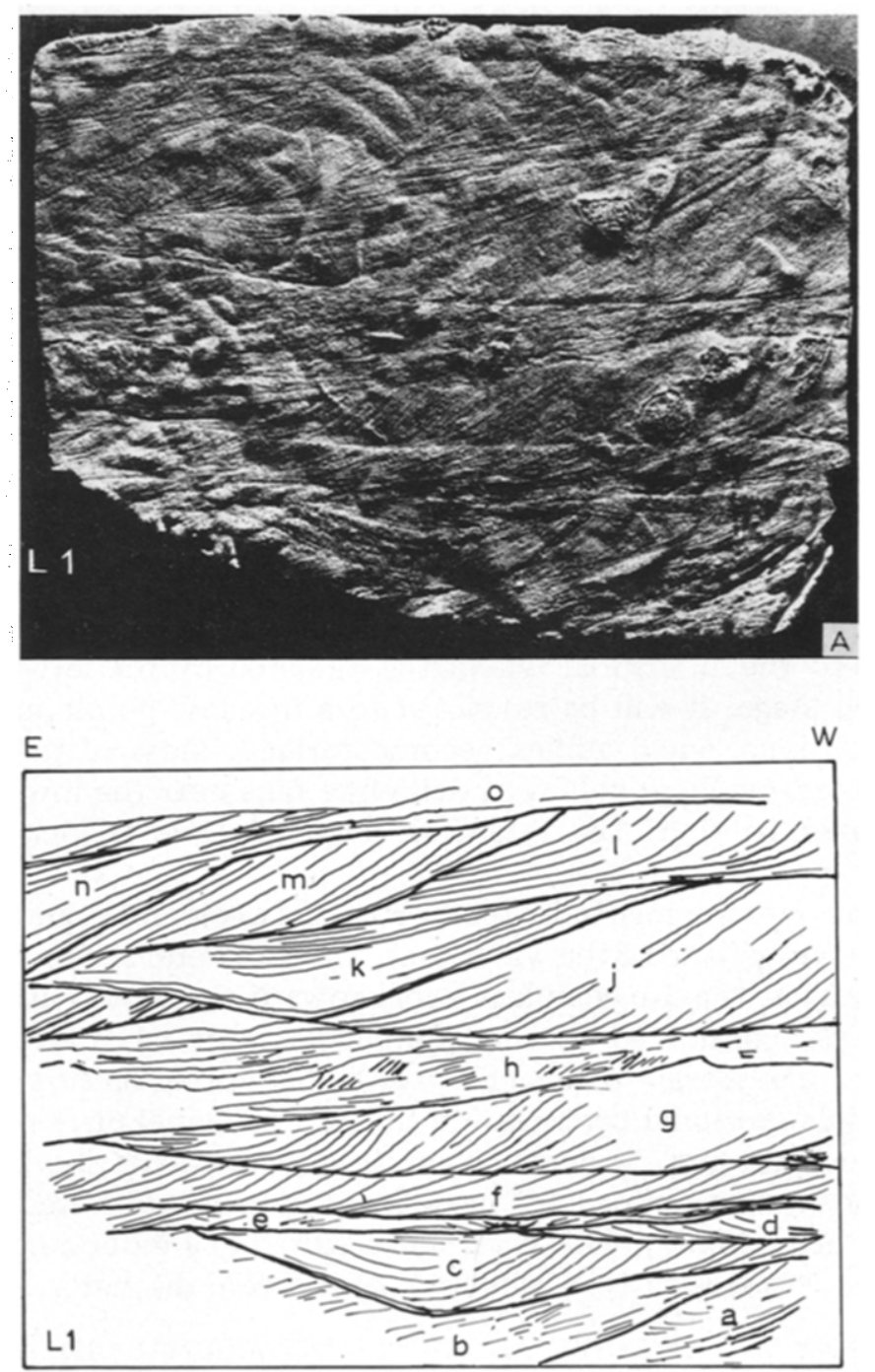

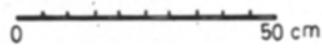

B

Fig. 8. (A,B). Preserved vertical sequence of the outer margin near the intershoal channel mouth. Flood current is to the left. For explanation, see text. 
hollows, which are filled in by small-scale ripplefans (Allen, 1968).

As the water rises, flood currents turn from a southeastern direction along the interchannel outer bend and margin to a more easterly direction as soon as the shoal becomes inundated. The ebb current may temporarily modify the steep accretional slope faces of the flood-oriented ripples into more gently inclined slopes. Because of the proximity of the Hammen, wave action is important. With higher wave action, the steady development of tidal currents will be disturbed by wave oscillations and discontinuous wave-induced currents, which will affect the formation and erosion of the large-scale bedforms.

Echo-sounding profiles indicate that the sampled sequence is deposited recently and more or less within the same environmental setting (see Fig. 7, location Ll). The sequence is characterized by a succession of irregular bounded sets of flood-oriented large-scale cross-strata. The foresets are concave-upward and have well-developed tangential bottomsets. The shape and angle of foresets are variable.

Units $c, k$ and $h$ (Fig. 8B) show infilling structures of the hollows. Note the difference of the infilling structures; units $c$ and $k$ have festoon-like structures and unit $h$ has small-scale cross-laminations, probably produced by ripplefans.

Many of these structural features reflect the irregular nature of bedform development in this particular area. The formation of clay drapes during the turn of the tide is generally inhibited by wave action but occasionnally takes place (see Fig. 8B, unit a).

(2) Figs. 9 (A and $B$ ) represent a vertical sequence, that is located somewhat higher on the outer channel margin (see Fig. 4 for location). The sequence can be divided into two distinct intervals.

The lower interval consists of flood-oriented large-scale, low-angle laminae and superimposed small-scale cross-laminations with ill-defined set boundaries. Current orientation of these small-scale ripples show flood-as well as ebb-directions. Echo-sounding profiles taken in the period between 1959 and 1976 (Fig. 7) and the structural organization indicate that this interval probably is a preserved remnant of a former inner margin (see also next section).

The upper interval consists of a coset of large-scale planar cross-strata. Set geometry and directional parameters of the large-scale cross-strata are related to the flood-dominated, long-crested sand waves, which were the dominant bedform type during our investigations. We can assume that the present-day flow conditions are similar to those during the deposition of the upper interval of the sequence.

Small-scale cross-laminations formed by the less important ebb currents can be observed in the upper set. These small-scale isolated ripple trains climb high up the slightly flattened lee-side of the sand waves. Within the preserved sequence these small-scale ebb cross-laminations appears on the slightly truncated large-scale foresets of the sand waves. Ebb currents are 

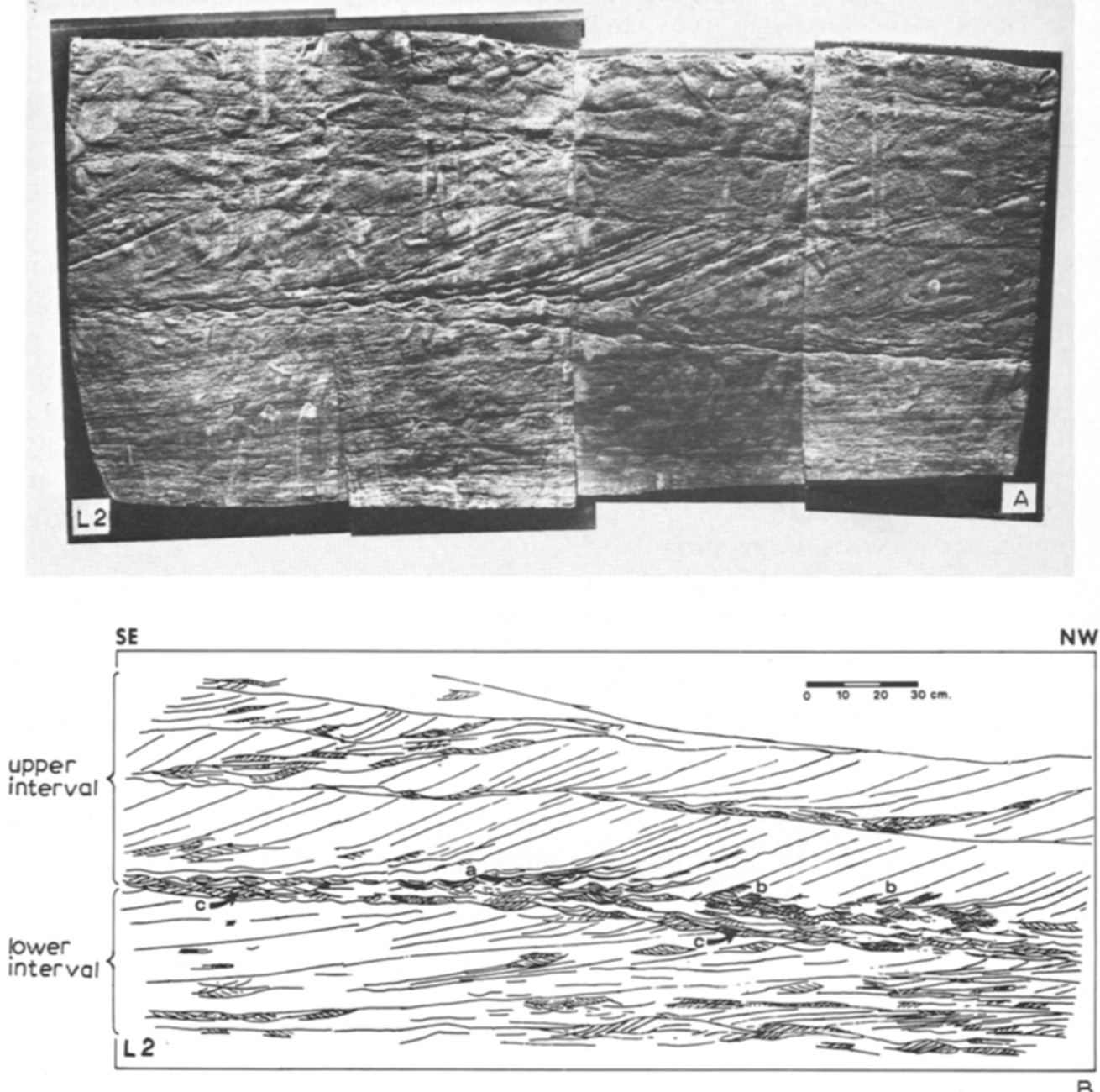

Fig. 9. (A,B). Preserved vertical sequence of the outer margin. Flood current is to the left. For explanation, see text.

also responsible for the deposition of silty-clay drapes on the large-scale foresets. These silty-clay intercalations can be traced down to the bottomsets, where they cover the small-scale ripples ( $a$ in Fig. 9B).

An interesting feature is the development of well-preserved backflow ripple laminations within the bottomsets ( $b$ in Fig. 9B). Backflow ripples have been described from fluviatile and inner estuarine deposits of the Lower Rhine (Boersma, 1967: Boersma et al., 1968; De Raaf and Boersma, 1971). Remarkable is also the preservation of coflow ripples ( $c$ in Fig. 9B), which show a slightly climbing tendency within the lower part of the bottomsets. Only part of the bottomset layers consist of distinct backflow and coflow 
laminations. Another part is composed of more or less climbing, polydirectional cross-laminations. Some of these cross-lamiantions might be produced in the transition zone between backflow and coflow at flood tide. Others are probably formed by the weaker ebb currents or by wave action.

The well-developed bottomset layer within the lower set of the upper interval indicates the existence of a relatively high suspended flow. The presence of backflow ripples also indicates the existence of relatively low velocity currents. According to Boersma (1967) backflow processes should be incompetent to erode and to remove all the material that rains down from the suspended load in its flow-impinged area. The presence of mediumto fine-grained, not well-sorted, sand is in accordance with the presence of the described bedforms and their related sedimentary structures.

The top of the upper interval is disturbed due to sampling.
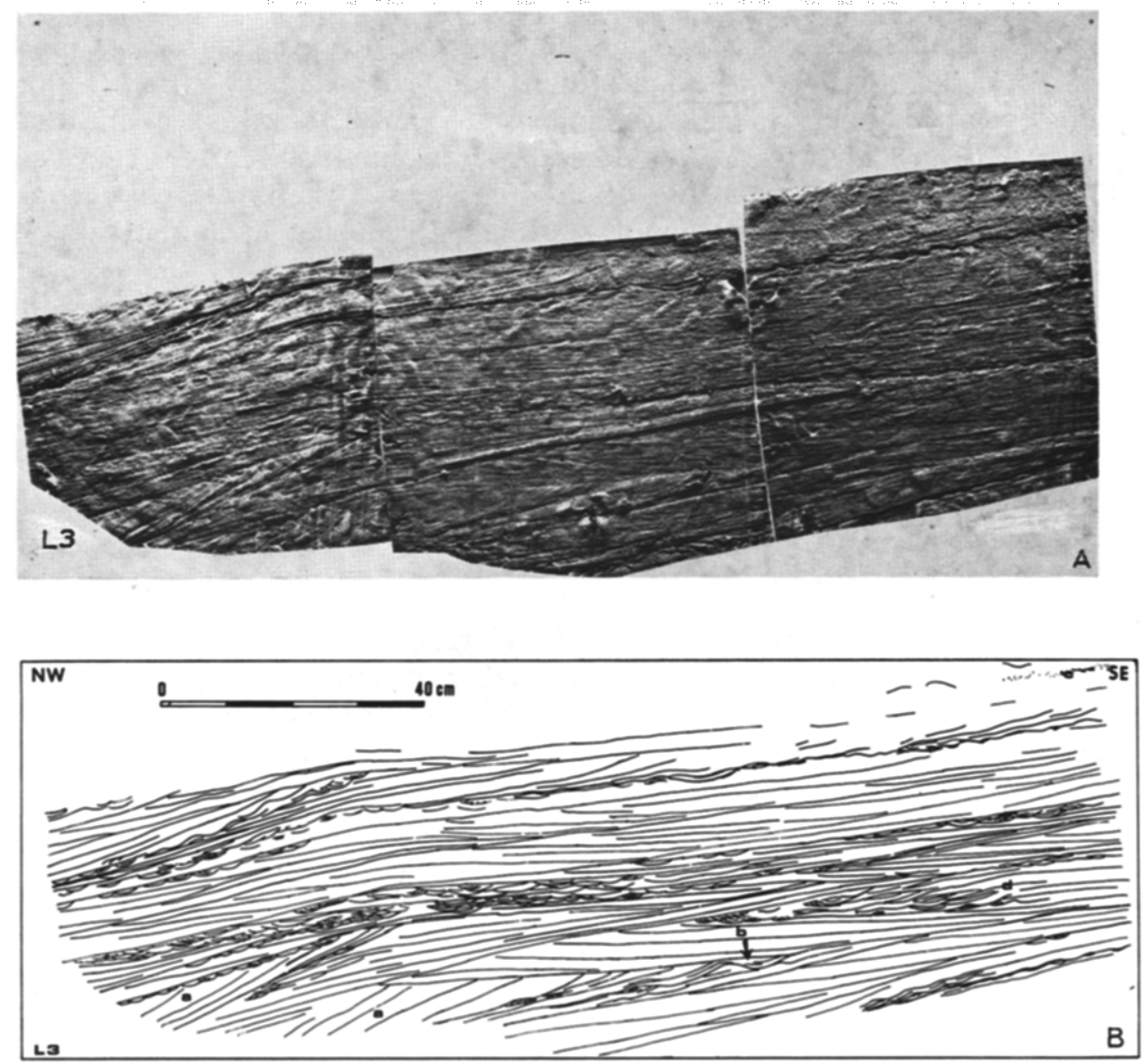

Fig. 10. (A,B). Preserved vertical sequence of the upper part of the inner margin. For explanation, see text. 
(3) The vertical sequence shown in Fig. 10 has been sampled from the levee within the inner channel margin (see Fig. 4, location L3). The depositional processes within this zone have been described earlier and, in accordance to that description, bedforms mainly consist of flat surfaces associated with patches of small-scale wave and current ripples.

The vertical sequence shows a succession of several units consisting of low-angle laminae. All the beds and laminae generally dip toward the intershoal channel. The dip of the laminae within the upper part of the sequence is between $2^{\circ}$ and $5^{\circ}$; in the lower part of the sequence, however, steeper dipping laminae can be observed ( $a$ in Fig. 10B). Dip angles can reach as high as $28^{\circ}$. All units are well defined by planar erosional surfaces. The uppermost part of the sequence shows an interesting bread-like texture Fig. 10A which is produced by entrapped air. Occurrence and formation of these structures in relation to tidal processes has been described by De Boer (1979).

Individual units of low-angle laminae are formed during periods of moderate to strong onshore winds at flood tide. High-velocity currents flow downslope producing low-angle laminations and occasionally antidune structures ( $b$ in Fig. 10B). Lower along the slope, however, current velocities will decrease drastically because of the influence of the intershoal channel and small-scale cross-laminations are formed, that occur in the lateral continuation of the low-angle laminae ( $d$ in Fig. 10B).

The accretional slope will become increasingly steep in a downslope direction during deposition, which corresponds to the occurrence of highangle cross-laminations in the lower part of the sequence. The following ebb currents tend to flatten the convex accretional slope, hence the formation of the planar erosional set boundaries. Note also that the dips of the erosional surfaces are intermediate between the low- and high-angle laminae.

\section{CONCLUSIONS}

Due to an overall sediment accumulation within the investigated area, net sedimentation also occurs within each subenvironment. Important differences in the sequential development of the several parts of such a shoal and intershoal channel complex occur.

(1) Owing to the lateral shifting of the intershoal channel, net sedimentation within the inner margin is dominant. Net sedimentation within the outer margin, on the contrary, is minimal. Consequently, the preservation potential of sedimentary structures within the inner margin will be considerably higher as compared to those of the outer margin.

(2) The ultimate result of a preserved sequence of a mesotidal shoal and intershoal channel complex is shown in Fig. 11. An important aspect is the contradiction between the occurrence of the bedforms in such an environment and the sequential succession of sedimentary structures. The preserved sequence will mostly show a succession of horizontal to low-angle 


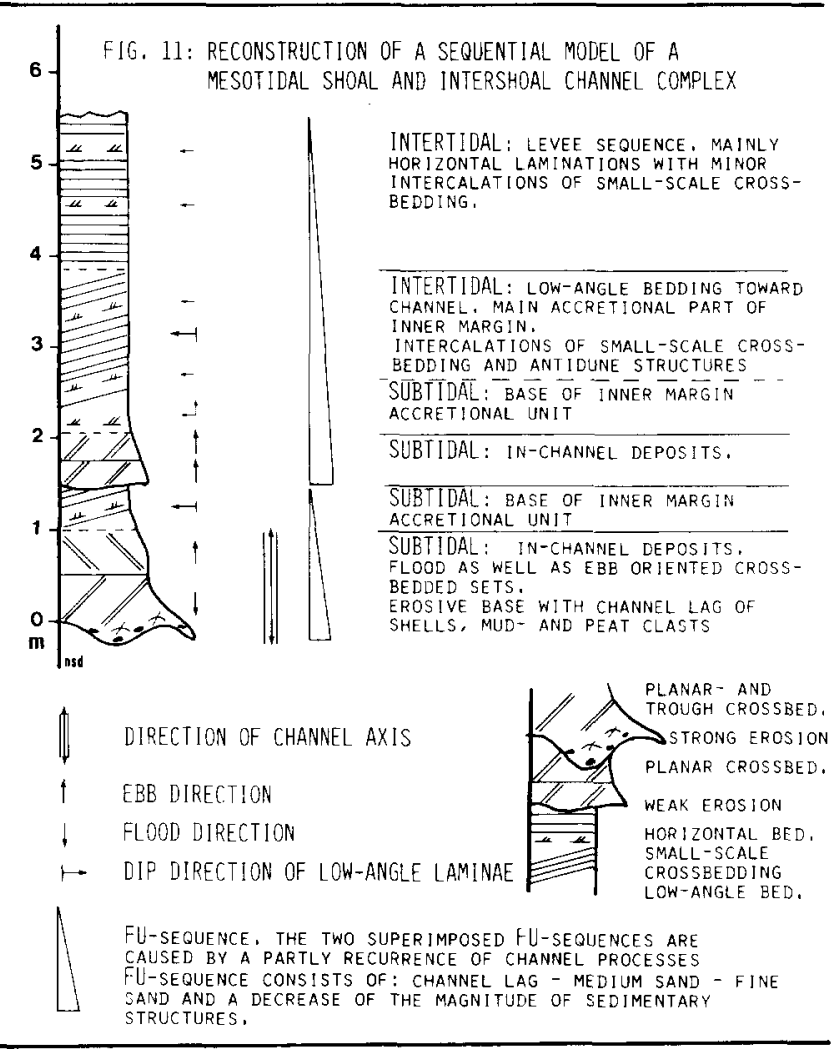

Fig. 11. Reconstructed sequential model of a mesotidal shoal and intershoal channel complex.

laminated sets with intercalations of small-scale cross-bedded units. The presence of larger-scale structures is distinctly limited. Larger-scale bedforms, however, are abound at the surface of the investigated area (see Fig. 4).

(3) The sequential model shown in Fig. 11 can be used in interpreting ancient analoguous deposits. Based on the dimension of the sedimentary structures one will conclude that low-energy depositional processes were dominant. Present studies showed, however, that relatively high-energy processes ultimately can have produced a sequential upbuilding consisting of small-scale structures.

(4) The studies also have shown that shoal accretion is realized by the migrational pattern of the small and numerous intershoal channels and, to a lesser degree, by the surrounding larger tidal channels.

(5) The lateral bedform sequence in the outer margin, which consists of highly erosive, catenary, large-scale ripples to more regular, long-crested sand waves is also observable in different sequential upbuilding (compare Figs. 8 and 9). Relatively short and erosive sets characterize the sequence 
in an area, where unstable and high-energy tidal currents are dominant. The sequence within the sand-wave area, which is characterized by stable and lower-energy tidal currents, consists of long sets with a more or less regular pattern of foreset bundles.

\section{ACKNOWLEDGEMENTS}

The authors are grateful for the support of Rijkswaterstaat and the Geological Survey of The Netherlands. We thank F. Spaargaren, T.J. Boon, H. Speekenbrink, R. van Vechgel of Rijkswaterstaat and R.T.E. Schüttenhelm and E. de Mulder of the Geological Survey for the fruitful discussions and their personal help.

Members of our Research Group, especially E. Nickel, C. Siegenthaler, P.L. de Boer, A. Ratering and P. Stienstra were actively involved in the pro. ject and in the manuscript preparation.

We are also grateful for the technical assistance of $\mathrm{H}$. Wijland.

\section{REFERENCES}

Allen, J.R.L., 1968. Current Ripples: their Relation to Patterns of Water and Sediment Motion. North-Holland, Amsterdam, $433 \mathrm{pp}$.

Allen, J.R.L. and Friend, P.F., 1976. Changes in intertidal dunes during two spring neap cycles, Lifeboat Station Bank, Wells-next-the-Sea, Norfolk (England). Sedimentology, 23: 329-346.

Boersma, J.R., 1967. Remarkable types of mega cross-stratification in the fluviatile sequence of a subrecent distributary of the Rhine, Amerongen, The Netherlands. Geol. Mijnbouw, $46: 217-235$.

Boersma, J.R., 1969. Internal structure of some tidal megaripples on a shoal in the Westerschelde estuary, The Netherlands; report of a preliminary investigation. Geol. Mijnbouw, 48: 409-414.

Boersma, J.R., Van de Meene, E.A. and Tjalsma, R.C., 1968. Intricated cross-stratification due to interaction of a megaripple with its lee-side system of backflow ripples (upper-pointbar deposits, Lower Rhine). Sedimentology, 11: 147-162.

Boothroyd, J.C., 1969. Hydraulic conditions controlling the formation of estuarine bedforms. In: Coastal Environments: NE Massachusetts and New Hampshire. Univ. Mass. Dep. Geol. Publ. Ser., Contrib. 1-CRG: 417-427.

Boothroyd, J.C. and Hubbard, D.K., 1975. Bedform development and distribution pat tern, Parker and Essex estuaries. U.S. Army Corps Eng., Coast. Eng. Res. Cent. Misc. Pap., 1-74,

Bouma, A.H., 1969. Methods for the Study of Sedimentary Structures.Wiley, New York; N.Y., $458 \mathrm{pp}$.

Davies, J.L., 1964. A morphogenic approach to world shorelines. Z. Geomorphol, 8: $27-42$.

De Boer, P.L., 1979. Convolute lamination in modern sands of the estuary of the Oosterschelde, The Netherlands, formed as the result of entrapped air. Sedimentology, 26: 283-294.

De Raaf, J.F.M. and Boersma, J.R., 1971, Tidal deposits and their sedimentary structures. Geol. Mijnbouw, 59: 479-504. 
Fermont, W., 1977. Holocene geologie van de Oosterschelde en directe omgeving. Comp. Sedimentol. Res. Group, Prog. Rep., 4: $31 \mathrm{pp}$.

Hayes, M.O., 1975. Morphology of sand accumulation in estuaries: an introduction to the symposium. In: Estuarine Research, 2. Academic Press, New York, N.Y., pp. $3-22$.

Hayes, M.O., 1980. General morphology and sediment patterns in tidal inlets. Sediment. Geol., 26: 139-156.

Howard, J.D. and Frey, R.W., 1975. Regional animal-sediment characteristics of Georgia estuaries. Senckenbergiana Mar., 7: 1-104.

King, C.A.M. and Williams, W.W., 1949. The formation and movement of sand bars by wave action. Geogr. J., 113: 70-85.

Klein, G. de V., 1970. Depositional and dispersal dynamics of intertidal sand bars. J. Sediment. Petrol, , 40: 1095-1127.

Oomkens, E. and Terwindt, J.H.J., 1960. Inshore estuarine sediments in the Haringvliet (Netherlands). Geol. Mijnbouw, 39: 701-710.

Reineck, H.E., 1967. Layered sediments of tidal flats, beaches and shelf bottoms of the North Sea. In: G.H. Lauff (Editor), Estuaries. Am. Assoc. Adv. Sci., 83: 191-206.

Reineck, H.E. and Singh, J.B., 1967. Primary sedimentary structures in the Recent sediments of the Jade, North Sea. Mar. Geol., 5: 227-235.

Reineck, H.E. and Wunderlich, F., 1969. Die Entstehung von Schichten und Schichtbänken im Watt. Senckenbergiana Mar., 1: 85-106.

Terwindt, J.H.J., 1971. Litho-facies of inshore estuarine and tidal-inlet deposits. Geol. Mijnbouw, 50: 515-526.

Terwindt, J.H.J., 1975. Sequences in inshore subtidal depostis. In: R.N. Ginsburg (Editor), Tidal Deposits. Springer, Berlin, pp. 85-89.

Van den Berg, J.H., 1977. A fast procedure for sampling sedimentary structures down to $1.10 \mathrm{~m}$ in unconsolidated wet sands. Geol. Mijnbouw, 56: 259-262.

Wilderom, M.H., 1964. Tussen afsluitdammen en deltadijken, 2. Schouwen-Duiveland. Littooy en Olthoff, Middelburg, $455 \mathrm{pp}$. 